\title{
Plant dispersal by Canada geese in Arctic Greenland
}

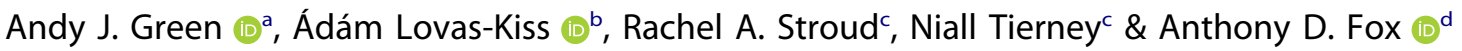

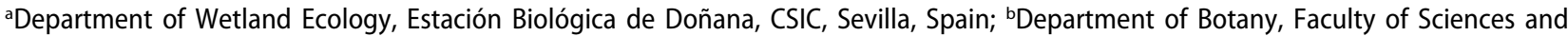 \\ Technology, University of Debrecen, Debrecen, Hungary; 'Faculty of Natural Resources and Environmental Sciences, Agricultural \\ University of Iceland, Hvanneyri, Iceland; dDepartment of Bioscience, Aarhus University, Rønde, Denmark
}

\begin{abstract}
Despite the abundance of migratory geese as herbivores in the Arctic, and ongoing changes in their populations and distributions, little is known about their role in seed dispersal. Climate change requires Arctic plants to adjust their distributions, and avian vectors may have an important role to play. We present the first study of endozoochory (internal transport) of Arctic plants by Canada geese. In central west Greenland, we collected 50 faecal samples, from which we extracted 2943 intact seeds from six species and four families, all but one of which (a non-native species) are extremely common and widespread in this part of Greenland. The majority (95\%) of seeds were from Empetrum nigrum, but Carex nardina (3\%) and Vaccinium uliginosum (2\%) were also abundant. One seed of the non-native Persicaria lapathifolia was recorded. These results suggest migratory geese are likely to be vital vectors of Arctic plants. Although the sample size was small, there were indications that nonbreeding geese may disperse more seeds than breeding geese, which stay closer to lakes to reduce the risk of predation, rarely accessing dwarf-scrub heath where non-breeders ingested seeds. Future research should address such possible links between reproductive status and seed dispersal in waterbirds.
\end{abstract}

\section{KEYWORDS}

Branta canadensis; Carex; Empetrum; endozoochory; faeces; seed dispersal
Arctic plant species assemblages are highly structured, on account of sequential Pleistocene glaciations and long-established physical barriers to dispersal and gene flow (such as mountain chains, glaciers and the oceans (Alsos et al. 2015; Eidesen et al. 2013) as well as biotic interactions such as herbivory (Post \& Pedersen 2008). Vertebrate seed dispersers are important to maintain and enhance Arctic plant community richness (Bruun et al. 2008). This is especially significant in these times of climate change, which is reducing the extent of sea and terrestrial ice, and affecting seasonality, precipitation and wind patterns. Changing climate and resultant short-term changes in the Arctic environment (for instance, in land ice cover) create new opportunities for colonization of novel plant species and genotypes, as well as imposing different templates for patterns of activity, growth, reproduction and dispersal of existing plant life forms in these regions (Klein et al. 2008). Such vegetation dynamics are dependent on effective dispersal processes, including endozoochory (dispersal of seeds and other diaspores via gut passage) by migratory geese and other herbivores. Although the role of Arctic geese as herbivores and in nutrient cycling is well documented (e.g., Ruess et al. 1989; Jefferies et al. 1994), only a handful of studies worldwide show that geese can disperse a variety of plants both with and without a fleshy fruit (García-Álvarez et al. 2015; Green et al. 2016). As yet there is almost no information on the roles geese may play in maintaining and enhancing the diversity of Arctic plant communities.

Here, we report on endozoochory by Canada geese (Branta canadensis interior) in a coastal area of central west Greenland, and consider their likely role as vectors in the local changes in cover of native and nonnative plant species. Although apparently present in west Greenland since at least the 1860s, Canada geese have recently increased in abundance and range in west Greenland and have colonized this specific study area since the 1980s (Malecki et al. 2000; Fox \& Glahder 2010; Fox et al. 2011; Fox et al. 2012).

\section{Study area, materials and methods}

The study area lies north and east of the town of Ilulissat $\left(69^{\circ} 13^{\prime} \mathrm{N} 51^{\circ} 6^{\prime} \mathrm{W}\right)$ in central west Greenland (Fig. 1). The area comprises a rocky plateau $100-400 \mathrm{~m}$ a.s.l. covered by dwarf-scrub heath vegetation. Dominant species are Cassiope tetragona, Empetrum nigrum and Vaccinium uliginosum microphyllum, with some graminoids, and on the dry barrens Dryas octapetala, Salix arctica and graminoids such as Carex nardina and Kobresia myosuroides. Wetter sites and lake margins are dominated by Eriophorum scheuchzeri and Carex rariflora. Canada geese spending the summer in this 


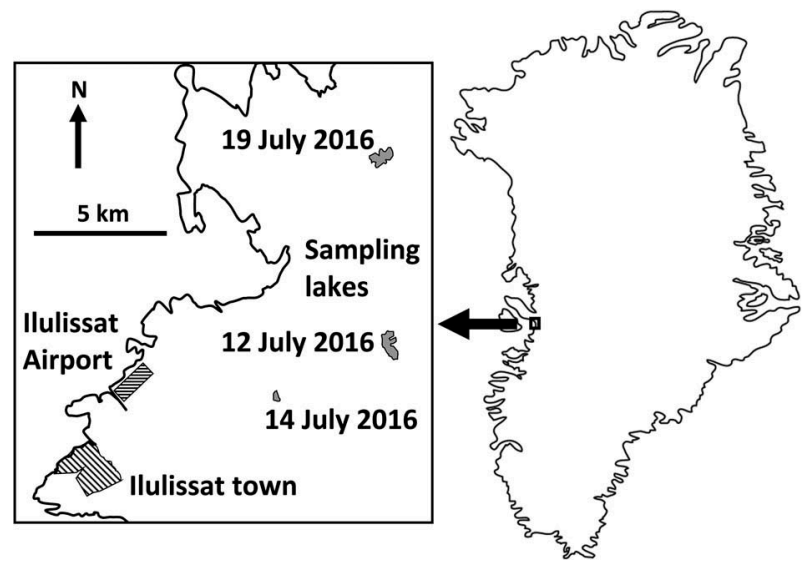

Figure 1. Study area in Greenland in relation to the town of Ilulissat.

area in July/early August comprise either moulting flocks of non-breeding (i.e., failed breeders or subadult individuals) or family groups of parents with goslings (too small to fly). All geese tend to resort to the open water of lakes and streams when threatened by predators such as Arctic fox (Vulpes lagopus), the only mammalian predator of this region, so tend to be constrained to feed close to water, although they will forage away from shorelines on relatively profitable food.

Fifty samples of fresh Canada goose droppings were collected from three sites near Ilulissat from 12 to 19 July 2016 within one to two hours of observing the birds feeding there (Fig. 1). Thirty-two faecal samples were obtained from a flock of 28 non-breeders moulting flight feathers on a lake at $69^{\circ} 19^{\prime} 08.0^{\prime \prime} \mathrm{N} 50^{\circ}$ $48^{\prime} 41.6^{\prime \prime} \mathrm{W}$ on 19 July 2016 , seven from nine nonbreeding moulters at $69^{\circ} 15^{\prime} 27.9^{\prime \prime} \mathrm{N} 50^{\circ} 48^{\prime} 05.6^{\prime \prime} \mathrm{W}$ on 12 July 2016 and 11 from a family of two adults (five faecal pellets mean dry mass $3.74 \mathrm{~g} \pm 0.82$ S.E.) and four goslings (six faecal pellets mean dry mass $2.06 \mathrm{~g} \pm 0.34$ S.E., judged on clear size difference to adult faeces from young aged 25-30 days old and half grown) on 14 July 2016 at $69^{\circ} 14^{\prime} 13.7^{\prime \prime} \mathrm{N} 50^{\circ} 54^{\prime} 34.0^{\prime \prime} \mathrm{W}$. Droppings from the non-breeder flock were $12-15 \mathrm{~mm}$ in diameter, adult droppings in the family groups were distinguishable in this way from the gosling faeces, which were ca. 5-8 mm diameter. Although the very slightly smaller Greenland white-fronted goose (Anser albifrons flavirostris) is endemic to west Greenland, this species was not observed during protracted exploration of the study area. This, together with our detailed observations of the Canada goose groups prior to faecal collection, gives us confidence that we sampled exclusively from this species. All samples were freshly collected and sun dried, placed in envelopes and transported in plastic bags to Hungary for further investigation. In Hungary, samples were kept refrigerated at $4^{\circ} \mathrm{C}$ until analysis. Samples were then soaked in deionized water, sieved with a $100 \mu \mathrm{m}$ sieve and deionized water, then inspected under a binocular microscope for plant diaspores. Only intact, uncracked seeds were extracted and quantified. The seeds were identified based on shape, size, colour and seed coat pattern, in accordance with the recent literature (Aiken et al. 2007; Cappers et al. 2012; USDA, NRCS 2018).

Viability tests were run for seeds on 1 August 2017, using the peroxidase test (Copeland \& McDonald 1999). For those species for which we extracted more than 50 seeds, we randomly selected a subset of 50 (Table 2). As a consequence of their smaller size, some of the V. uliginosum seeds were accidentally destroyed during the testing process, so that final sample size was 25 (Table 2). Seeds were soaked for $12 \mathrm{~h}$ in deionized water, cut in half and inspected to confirm the presence of an embryo. Half of each seed was immersed in $10 \% \mathrm{H}_{2} \mathrm{O}_{2}$ solution, drained off and the seeds were rinsed in $90 \%$ ethyl alcohol followed by $\mathrm{pH} 8$ phosphate buffer. Finally, the seeds were soaked in benzidine diluted in $80 \%$ ethyl alcohol, which immediately turns viable seeds to a distinctive dark colour.

\section{Results}

From the 50 dried samples (mean dry mass $=3.536 \mathrm{~g} \pm 2.39 \mathrm{~g}$ S.D.), we recovered a total of 2943 seeds, belonging to six species from four plant families (Table 1). Only one plant taxon was an aquatic emergent (Hippuris vulgaris); the remainder were terrestrial species. One family (Ericaceae) comprised two berry-bearing species; the others had no obvious adaptations for endozoochory. Overall, of all the faecal samples, $39(78 \%)$ contained at least one seed (Table 1). We found one seed from the non-native Persicaria lapathifolia in one sample from the non-breeding flock, a plant species occurring outside its natural range, introduced to Greenland through human agency (Böcher et al. 1978). Faecal samples from non-breeding flocks were rich in seeds, and $95 \%$ of these samples contained at least one seed. In contrast, only $18 \%$ of samples from the goose family contained any seeds (Table 1 ).

The peroxidase test confirmed viability for seeds of C. nardina, E. nigrum, V. uliginosum and P. lapathifolia (Table 2). We also recorded fragments of mosses or lichens in four of our samples, which potentially were viable at the time of egestion.

\section{Discussion}

We showed that Canada geese are potentially important seed vectors in the Arctic biome, and that they disperse a range of flowering plant taxa by endozoochory. We focussed our study on large diaspores preserved after drying, but it is also possible that the Canada geese were vectors for the spores or viable fragments of the mosses and lichens, which were additional components of their diet (Wilkinson 
Table 1. Plant diaspores recovered from Canada goose droppings in Greenland. Total number of intact seeds (TS), number of samples with seeds (NS) and maximum number of seeds in any given sample (Max).

\begin{tabular}{|c|c|c|c|c|c|c|c|c|c|}
\hline \multicolumn{4}{|c|}{ Plants } & \multicolumn{3}{|c|}{ Non-breeding $(\mathrm{n}=39)$} & \multicolumn{3}{|c|}{ Breeding $(n=11)$} \\
\hline Family & Species & Length $(\mathrm{mm})^{\mathrm{a}}$ & Dispersal syndrome $e^{b}$ & TS & NS & Max & TS & NS & Max \\
\hline \multirow[t]{2}{*}{ Cyperaceae } & Carex nardina & 2.22 & $N^{c}$ & 82 & 16 & 22 & - & - & - \\
\hline & Kobresia myosuroides & 2.63 & barochory & 8 & 6 & 3 & - & - & - \\
\hline \multirow[t]{2}{*}{ Ericaceae } & Empetrum nigrum & 1.85 & endozoochory & 2780 & 32 & 494 & 2 & 1 & 2 \\
\hline & Vaccinium uliginosum & 1.3 & endozoochory & 69 & 11 & 25 & - & - & - \\
\hline Plantaginaceae & Hippuris vulgaris & 1.85 & hydrochory & - & - & - & 1 & 1 & 1 \\
\hline \multirow[t]{2}{*}{ Polygonaceae } & Persicaria lapathifolia $^{\mathrm{d}}$ & 2.88 & barochory & 1 & 1 & 1 & - & - & - \\
\hline & Total & & & 2940 & 37 & 494 & 3 & 2 & 2 \\
\hline
\end{tabular}

a Length data were derived from the LEDA database (Kleyer et al. 2008) and our own measurements. ${ }^{\mathrm{b}}$ Dispersal syndromes were taken from Baseflor (Julve 1998): barochory implies self-dispersal via gravity, hydrozoochory implies water dispersal, endozoochory implies dispersal via frugivory. ${ }^{\mathrm{C}}$ No data because this species is not listed in Baseflor. Wind dispersal has been proposed elsewhere for C. nardina (Flora of Svalbard 2018). ${ }^{\mathrm{d}}$ Species not native to Greenland according to Böcher et al. (1978).

et al. 2017; Lovas-Kiss et al. 2018). Our conservative viability test, conducted a year after faeces were collected, confirmed viability of $>10 \%$ of seeds.

Our findings are consistent with previous studies suggesting that this goose species is an important plant vector in other biomes. Morton \& Hogg (1989) germinated seeds of three species from Canada geese faeces collected on an island in Georgian Bay, Great Lakes, including $V$. angustifolium, which did not grow on the island and was thought to be dispersed several kilometres from the lake shore. Neff \& Baldwin (2005) germinated six taxa from faeces in a freshwater marsh in Washington D.C. Best and Arcese (2009) germinated five taxa from faeces from islands near Vancouver. In the only previous study of endozoochory by Arctic geese we are aware of, Bruun et al. (2008) recorded viable seeds of 12 taxa (including $C$. nardina, K. myosuroides and $V$. uliginosum) in faeces of barnacle geese $B$. leucopsis in coastal north-east Greenland.

Canada geese have recently increased in abundance in west Greenland and can assist in the dispersal of native plant species that are shifting their distribution, as well as potentially with new additions to the Greenland flora, especially under a scenario of rapid climate change (Klein et al. 2008). They are also thought to be the vectors of local dispersal for Daphnia that rapidly colonize new ponds and lakes formed as ice retreats in western Greenland (Haileselasie et al. 2016). The appearance of a single seed of $P$. lapathifolia suggests geese have a role in the spread of non-native species in Greenland. This plant is also non-native in the Canadian Arctic (USDA, NRCS

Table 2. Viability of seeds recovered from Canada goose droppings in Greenland. Results of the peroxidase test for a subset of seeds, showing numbers of tested seeds (TS), seeds with an embryo (SE), and viable seeds (VS).

\begin{tabular}{llrrr}
\hline Family & \multicolumn{1}{c}{ Species } & TS & SE & VS \\
\hline Cyperaceae & Carex nardina & 50 & 7 & 4 \\
& Kobresia myosuroides & 8 & 0 & 0 \\
Ericaceae & Empetrum nigrum & 50 & 10 & 3 \\
& Vaccinium uliginosum & 25 & 12 & 6 \\
Plantaginaceae & Hippuris vulgaris & 1 & 0 & 0 \\
Polygonaceae & Persicaria lapathifolia & 1 & 1 & 1 \\
& Total & 135 & 30 & 14 \\
\hline
\end{tabular}

2018), and to date in west Greenland it is relatively restricted to the vicinity of human settlements along the coast. Geese and other waterbirds are known to disperse many non-native plants (Green 2016), and P. lapathifolia has been recorded as dispersed by European dabbling ducks (Green et al. 2016). On islands near Vancouver, Canada geese have been shown to play a key role in the spread of non-native grasses through both endozoochory and grazing (Best \& Arcese 2009).

Larger seeds are thought more likely destroyed during passage through the avian gut, so it is noteworthy that all the seeds we recorded were $>1 \mathrm{~mm}$ and $<3 \mathrm{~mm}$ long (in contrast to studies of endozoochory by European ducks (Soons et al. 2016; Lovas-Kiss et al. 2018). Two of the three most abundant angiosperms in our samples have a fleshy fruit characteristic of an endozoochory syndrome (Table 1). In contrast, half of the species we recorded are usually assumed to rely on gravity (barochory) or water (hydrochory) for their dispersal (Table 1). Although we sampled the geese at a time when they would probably deposit seeds only tens or hundreds of metres away from the mother plants, this is likely to be further than the seeds could disperse by other means such as water or wind (Bullock et al. 2017). This may therefore represent a vital process enabling changes in vegetation in response to climate change (Gonzalez-Varo et al. 2017). Furthermore, it is very possible that the geese can disperse these same plant species over hundreds of kilometres during their long-distance migrations in a similar manner to migratory ducks, since the longest seed retention times in the guts of geese exceed the time required for migration (Viana et al. 2013; García-Álvarez et al. 2015). Geese have not been shown to empty their digestive tract before migrations, and flight activity is likely to increase seed survival (Kleyheeg et al. 2015). A role for geese as long-distance vectors in Arctic environments is strongly consistent with genetic and floristic analyses (Alsos et al. 2015). All the plant species we recorded are widely distributed in Canada and the coastal USA (USDA, NRCS 2018), suggesting that Canada geese may have contributed as vectors to their broad distributions and to contemporary long-distance gene flow. 
In spite of the small sample size, our results also suggest that endozoochorous seed dispersal by Arctic geese can be affected by microhabitat use, which could potentially be related to social status. Different groups from within a given goose population that feed within the same landscape, but differ in social status, can show radically different diets. Our results are consistent with our direct field observations of Canada goose behaviour during the moult period. Non-breeding Canada geese tend to aggregate into relatively large flocks during the ca. three weeks they are flightless. During this time, they resort to the safety of open water bodies to avoid predation, largely from Arctic fox, but may feed out on dwarfscrub heath where their diet may be predominantly the berries of E. nigrum and V. uliginosum, which frequently form the dominant vegetation cover in areas of deeper soil. Empetrum berries provide relatively little metabolizable biomass for geese, but may provide critical antioxidants and fatty acids, which may be important for completion of moult and for successful autumn migration (e.g., Hupp et al. 2013). The larger flock size of nonbreeders enhances predator detection, enabling them to forage at greater distances from the water's edge than smaller groups of breeding pairs with their broods. Breeding groups tend to graze the aboveground growth of graminoids such as $C$. rariflora along lake shores, especially when goslings are very young, rarely leaving the safety of peripheral lake wetland habitats to ensure an escape route to open water. Hence, they do not tend to feed where the berries and dry habitat graminoids such as $C$. nardina occur. Given that we only collected faeces from breeding birds at a single site, however, we remain prudent about inferring much from the differences between these and the more abundant samples from non-breeders at two sites.

More detailed studies are required to fully investigate the role of Arctic geese as plant vectors at different spatial scales. This should include the influence of social status on microhabitat use and the quantity and quality (sensu Schupp et al. 2010) of seed dispersal, a research topic not yet addressed in waterbirds (Green et al. 2016).

\section{Acknowledgements}

This study was supported by Spanish Ministerio de Economía, Industria y Competitividad project CGL2016-76067-P (AEI/ FEDER, EU) to AJG. ALK was supported by the New National Excellence Program ÚNKP-17-3-I-DE-385. We greatly appreciate the help of Csaba Máthé, Márta Mikóné Hamvas and Tamás Garda in undertaking the viability tests. We thank Juan P. González-Vero and two anonymous referees for comments and suggestions that improved the article.

\section{Disclosure statement}

No potential conflict of interest was reported by the authors.

\section{Funding}

This work was supported by the New National Excellence Program (ÚNKP-17-3-I-DE-385) and the Spanish Economy Ministry (CGL2016-76067-P).

\section{ORCID}

Andy J. Green (1) http://orcid.org/0000-0002-1268-4951

Ádám Lovas-Kiss (10) http://orcid.org/0000-0002-8811-1623

Anthony D. Fox (D) http://orcid.org/0000-0001-8083-7633

\section{References}

Aiken S.G., Dallwitz M.J., Consaul L.L., McJannet C.L., Boles R.L., Argus G.W., Gillett J.M., Scott P.J., Elven R., LeBlanc M.C., Gillespie L.J., Brysting A.K., Solstad H. \& Harris J.G. 2007. Flora of the Canadian Arctic Archipelago: descriptions, illustrations, identification, and information retrieval. Ottawa: NRC Research Press, National Research Council of Canada. Accessed on the internet at http://nature.ca/ aaflora/data on 3 June 2017.

Alsos I.G., Ehrich D., Eidesen P.B., Solstad H., Westergaard K. B., Schönwetter P., Tribsch A., Birkeland S., Elven R. \& Brochmann C. 2015. Long-distance plant dispersal to North Atlantic islands: colonization routes and founder effect. AoB PLANTS 7, plv036, doi: 10.1093/aobpla/plv036.

Best R.J. \& Arcese P. 2009. Exotic herbivores directly facilitate the exotic grasses they graze: mechanisms for an unexpected positive feedback between invaders. Oecologia 159, 139-150.

Böcher T.W., Fredskild B., Holmen K. \& Jakobsen K. 1978. Grønlands flora. (Greenland's flora.) Copenhagen: P. Haase \& Søns Forlag.

Bruun H.H., Lundgren R. \& Phillip M. 2008. Enhancement of local species richness in tundra by seed dispersal through the guts of muskox and barnacle goose. Oecologia 155, 101-110.

Bullock J.M., Gonzalez L.M., Tamme R., Gotzenberger L., White S.M., Partel M. \& Hooftman D.A.P. 2017. A synthesis of empirical plant dispersal kernels. Journal of Ecology 105, 6-19.

Cappers R.T.J., Bekker R.M. \& Jans J.E.A. 2012. Digitale zadenatlas van Nederland. Digital seed atlas of the Netherlands. 2nd edn. Groningen: Barkhuis.

Copeland L.O. \& McDonald M.B. 1999. Seed viability testing. In L.O. Copeland \& M.B. McDonald (eds.) Principles of seed science and technology. Pp. 111-126. Boston: Springer.

Eidesen P.B., Ehrich D., Bakkestuen V., Alsos I.G., Gilg O., Taberlet P. \& Brochman C. 2013. Genetic roadmap of the Arctic: plant dispersal highways, traffic barriers and capitals of diversity. New Phytologist 200, 898-910.

Flora of Svalbard 2018. The flora of Svalbard. Accessed on the internet at http://svalbardflora.no on 1 August 2018.

Fox A.D. \& Glahder C.M. 2010. Distribution and abundance of post moulting white-fronted and Canada geese in west Greenland 2007. Polar Research 29, 413-420.

Fox A.D., Mitchell C., Weegman M.D., Griffin L., Thomas H., Stroud D.A. \& Francis I.S. 2011. Potential factors influencing increasing numbers of Canada geese in Isunngua, west Greenland. Wildfowl 61, 30-44.

Fox A.D., Sinnett D., Baroch J., Stroud D.A., Kampp K., Egevang C. \& Boertmann D. 2012. The status of Canada goose subspecies in Greenland. Dansk Ornitologisk Forenings Tidsskrift 106, 87-92. 
García-Álvarez A., Van Leeuwen C.H.A., Luque C.J., Hussner A., Vélez-Martín A., Pérez-Vázquez A., Green A.J. \& Castellanos E.M. 2015. Internal transport of alien and native plants by geese and ducks-an experimental study. Freshwater Biology 60, 1316-1329.

Gonzalez-Varo J.P., Lopez-Bao J.V. \& Guitian J. 2017. Seed dispersers help plants to escape global warming. Oikos 126, 1600-1606.

Green A.J. 2016. The importance of waterbirds as an overlooked pathway of invasion for alien species. Diversity and Distributions 22, 239-247.

Green A.J., Brochet A.L., Kleyheeg E. \& Soons M.B. 2016. Dispersal of plants by waterbirds. In C.H. Şekercioğlu et al. (eds.): Why birds matter: avian ecological function and ecosystem services. Pp. 147-195. Chicago: University of Chicago Press.

Haileselasie T.H., Mergeay J., Weider L.J., Jeppesen E. \& De Meester L. 2016. Colonization history and clonal richness of asexual Daphnia in periglacial habitats of contrasting age in west Greenland. Journal of Animal Ecology 85, 1108-1117.

Hupp J.W., Safine D.E. \& Nielson R.W. 2013. Response of cackling geese (Branta hutchinsii taverneri) to spatial and temporal variation in the production of crowberries on the Alaska Peninsula. Polar Biology 36, 1243-1255.

Jefferies R.L., Klein D.R. \& Shaver G.R. 1994. Vertebrate herbivores and northern plant communities: reciprocal influences and responses. Oikos 71, 193-206.

Julve P. 1998. Baseflor. Index botanique, écologique et chorologique de la flore de France. (Baseflor. Botanical, ecological and chorological index of the flora of France.) Lille: Institut Catholique de Lille. Accessed on the internet at http:// perso.wanadoo.fr/philippe.julve/catminat.htm on 15 June 2016.

Klein D.R., Bruun H.H., Lundgren R. \& Phillip M. 2008. Climate change influences on species interrelationships and distributions in high-Arctic Greenland. Advances in Ecological Research 40, 81-100.

Kleyer M., Bekker R.M., Knevel I.C., Bakker J.P., Thompson K., Sonnenschein M., Poschlod P., Van Groenendael J.M., Klimeš L., Klimešová J., Klotz S., Rusch G.M., Hermy M., Adriaens D., Boedeltje G., Bossuyt B., Dannemann A., Endels P., Götzenberger L., Hodgson J.G., Jackel A.-K., Kühn I., Kunzmann D., Ozinga W.A., Römermann C., Stadler M., Schlegelmilch J., Steendam H.J., Tackenberg O., Wilmann B., Cornelissen J.H.C., Eriksson O., Garnier E. \& Peco B. 2008. The LEDA traitbase: a database of life-history traits of northwest European flora. Journal of Ecology 96, 1266-1274.

Kleyheeg E., Van Leeuwen C.H.A., Morison M.A., Nolet B.A. \& Soons M.B. 2015. Bird-mediated seed dispersal: reduced digestive efficiency in active birds modulates the dispersal capacity of plant seeds. Oikos 124, 899907.

Lovas-Kiss Á., Vizi B., Vincze O., Molnár V.A. \& Green A. J. 2018. Endozoochory of aquatic ferns and angiosperms by mallards in central Europe. Journal of Ecology 106, 1714-1723.

Malecki R.A., Fox A.D. \& Batt B.D.J. 2000. An aerial survey of nesting white-fronted and Canada geese in west Greenland. Wildfowl 51, 49-58.

Morton J.K. \& Hogg E.H. 1989. Biogeography of island floras in the Great Lakes. 2. Plant dispersal. Canadian Journal of Botany-Revue Canadienne de Botanique 67, 1803-1820.

Neff K.P. \& Baldwin A.H. 2005. Seed dispersal into wetlands: techniques and results for a restored tidal freshwater marsh. Wetlands 25, 392-404.

Post E. \& Pedersen C. 2008. Opposing plant community responses to warming with and without herbivores. Proceedings of the National Academy of Sciences 105, 12353-12358.

Ruess R.W., Hik D.S. \& Jefferies R.L. 1989. The role of lesser snow geese as nitrogen processors in a sub-Arctic salt marsh. Oecologia 79, 23-29.

Schupp E.W., Jordano P. \& Gomez J.M. 2010. Seed dispersal effectiveness revisited: a conceptual review. New Phytologist 188, 333-353.

Soons M.B., Brochet A., Kleyheeg E., Green A.J. \& Jongejans E. 2016. Seed dispersal by dabbling ducks: an overlooked dispersal pathway for a broad spectrum of plant species. Journal of Ecology 104, 443-455.

USDA, NRCS 2018. Plants Database. National Plant Data Team, Natural Resources Conservation Service, US Department of Agriculture, Greensboro, NC 27401-4901 USA. Accessed on the internet at http://plants.usda.gov on 1 August 2018.

Viana D.S., Santamaria L., Michot T.C. \& Figuerola J. 2013. Allometric scaling of long-distance seed dispersal by migratory birds. American Naturalist 181, 649662.

Wilkinson D.M., Lovas-Kiss Á., Callaghan D.A. \& Green A.J. 2017. Endozoochory of large bryophyte fragments by waterbirds. Cryptogamie Bryologie 38, 223-228. 